\section{Aquatic ecotoxicology: what has been accomplished and what lies ahead? An Eastern Canada historical perspective}

\author{
Christian Blaise, François Gagné \\ Aquatic Contaminants Research Division, \\ Environment Canada, Montréal, Québec, \\ Canada
}

\section{Abstract}

Our recent history shows that degradation of aquatic ecosystems essentially stems from industrialization, urbanization and increasing human populations. After a first industrial boom in the late $19^{\text {th }}$ century, contamination pressures on receiving waters now appear to be continual because of expanding economies and technologies developing at the planetary scale. Given the diversity of issues, problems and challenges facing water quality today because of complex waste and chemical discharges into waterways, aquatic ecotoxicology has blossomed with time into a more mature discipline of the environmental sciences. Its two fundamental pillars, bioassays and biomarkers, have become essential tools that allow the determination of numerous and versatile effects measurements. Herein, we demonstrate some of the ways in which these tools have been applied and how they have evolved over the past decades to appraise the ecotoxicity of contaminants impacting aquatic systems. Examples discussed are largely reflective of work conducted in the Environment Canada (EC) laboratories (SaintLawrence Centre, Montréal, Canada). Success stories include improvement of industrial effluent quality contributing to beluga whale population recovery in the Saint-Lawrence River, biomarker field studies conducted with endemic and caged bivalves to more fully comprehend urban effluent adverse effects, and increased discernment on the hazard potential posed by emerging classes of chemicals. Ecotoxicology continues to be confronted with diverse issues and needs related to a myriad of chemical contaminants released to aquatic environments worldwide. To cope with these, ecotoxicology will have to bank on new tools (e.g., toxicogenomics, bio-informatics, modeling) and become more interdisciplinary by taking into account knowledge provided by other disciplines (e.g., ecology, chemistry, climatology, microbiology) in order to more fully understand and adequately interpret hazard. This will be paramount to supply regulators and legislators with the sound and scientifically valid information needed in order to mitigate environmental degradation.

\section{Introduction}

Since its modest beginnings in the second half of the $20^{\text {th }}$ century, the field of ecotoxicology has unquestionably matured and is now positioned to produce knowledge that can be used more reliably to take enlightened decisions to safeguard the quality of aquatic environments. Clearly, activities and expertise in aquatic toxicology, which began in various parts of the world, have differed based on several types of considerations. For example, specific geographical contaminant issues, access to adequate human and financial resources, presence/absence of national statutes ensuring environmental protection, as well as enforcement policies, are factors that weigh markedly in the orientation that applied research laboratories will have taken to facet their (sometimes rather unique) ecotoxicological know-how. In this review, we essentially present a selection of highlights of ecotoxicological investigations conducted in our EC laboratories in Montreal (Centre Saint-Laurent, Québec, Canada) aimed at protecting and conserving the aquatic resources and uses of the Saint-Lawrence River under the aegis of several five-year Saint-Lawrence River Action Plans commencing in 1988. Its contents expose some of the contaminant pressures faced by this major Canadian River composed of both a freshwater and an estuarine stretch. Moreover, the historical background recalled on the early origins of ecotoxicology, and its evolution thereafter, should prove of interest, in general to the scientific community at large, and in part to younger up-and-coming scientists, as it provides time-related information that spans over several generations.

\section{Industrial revolutions and ecotoxicity: historical background}

The first industrial revolution of modern times began in England during the latter half of the $19^{\text {th }}$ century when extensive mechanization, urban concentration of labor and increased use, and transformation of, (non)renewable resources contributed to large-scale production of goods. Rapidly expanding to other parts of Europe and North America, this technology (and profit)-driven economic development was undoubtedly useful to enhance the quality of life of one species on this planet, namely Homo sapiens. Industrial
Correspondence: Christian Blaise, Aquatic Contaminants Research Division, Environment Canada, 105 McGill, $7^{\text {th }}$ floor, Montréal, Québec, Canada, H2Y 2 E7.

Tel. +1.514.496.7094 - Fax: +1.514.496.7398.

E-mail: christian.blaise@ec.gc.ca

Key words: aquatic ecotoxicity, bioassays, biomarkers, urban effluents, emerging substances.

Acknowledgments: the authors would like to thank Environment Canada (Water Science and Technology Directorate) for permission to present this review of ecotoxicological research conducted in our laboratories in Montreal (Aquatic Contaminants Research Division, Centre SaintLaurent group).

Contributions: equal contribution by both authors in laboratory and fieldwork, as well as in data analysis/interpretation and writing of manuscript.

Conflict of interests: the authors declare no potential conflict of interests.

Funding: this work was funded by the StLawrence River Action plan relating to impacts of urban pollution on aquatic ecosystems. For work presented on emerging substances, research funding, obtained from the Nano-Canadian Environmental Protection Act Program of Environment Canada as well as from the Chemical Management Plan (Health Canada), is gratefully acknowledged.

Conference presentation: highlights of research described in this article were presented as an invited talk given by the first author during ISTA 16 (16th International Symposium on Toxicity Assessment) held in Cape Town, South Africa, February 21-26, 2013.

Received for publication: 24 May 2013. Revision received: 23 August 2013. Accepted for publication: 24 August 2013.

This work is licensed under a Creative Commons Attribution NonCommercial 3.0 License (CC BYNC 3.0)

CCCopyright C. Blaise and F. Gagné, 2013

Licensee PAGEPress, Italy

Journal of Xenobiotics 2013; 3:e8

doi:10.4081/xeno.2013.e8

revolutions have been on-going ever since, driven by unrelenting progress, as emerging economies are ever eager to join the global economic bandwagon.

With time, constant growth stimulated by the first $19^{\text {th }}$ century industrial boom created noticeable impacts on aquatic, terrestrial and atmospheric environments. Insidiously, on arrival of the 1950s, massive discharges of untreated wastewaters, and of specific chemical contaminants, led to visibly degraded 
aquatic environments. ${ }^{1}$ While there was an evident awareness of pollution problems, remediation responses were limited owing to lack of knowledge, tools and strategies to tackle environmental damage. This age of darkness decade, however, was soon followed by one that can be termed the beginning of enlightenment in the ensuing decade. Indeed, the 1960s saw the initial undertaking of fish bioassays whose results confirmed that industrial effluents were clearly deleterious to aquatic life! Owing in part to the generation of these bioanalytical data, which introduced a new concept - that of environmental toxicity - many industrialized countries (notably those regrouped under the Organization for Economic Co-operation and Development banner) found it appropriate to create environmental agencies to cope with rampant aquatic contamination during the regulatory 1970s. Environment Canada, for example, came into being in 1971, and immediately sought to tackle and resolve the acute toxicity issue linked to industrial point sources of pollution in Canada. This was ensured via statutes requiring effluent compliance based on both chemical and toxicity parameters. Indeed, enactment of the Fisheries Act in 1972 indicating that No person shall deposit or permit the deposit of a deleterious substance of any type in water frequented by fish... triggered effects-based regulations that proved paramount in curbing industrial effluent toxicity. Whereas acute lethality toward salmonid fish could occur at extremely low concentrations in the 1970 s with reported 96 -h $50 \%$ lethal concentrations (LC50) as low as $0.1 \% \mathrm{v} / \mathrm{v}$ for effluents, ${ }^{2}$ virtually all industrial discharges in Canada are now devoid of such effects. The 1970 s also marked the official birth of the discipline of ecotoxicology. In what is likely the earliest publication featuring the word ecotoxicology, Jean-Michel Jouany, professor of biology and pharmacy at the University of Rouen who pioneered the field of environmental toxicology in France, wrote in a 1971 article that ...the study of the influence of nuisances on the relationship existing between an individual [species] and his environment could simply be termed 'ecotoxicology' [translated from French]. ${ }^{3}$ In the 1980 s, several microbiotests (also called small-scale toxicity tests), working alongside combined biological/chemical hazard assessment strategies, were developed with (micro)organisms representative of decomposers, primary producers, as well as primary and secondary consumers to augment the ecotoxicity knowledge of contaminants. A concept prevailing during this decade was that all aquatic species would be protected provided the most sensitive one was safeguarded. ${ }^{4}$ This decade of holistic thought was followed by one featuring miniaturization and robotization of microbiotests to deal with an ever growing number of environmental samples requiring toxicity appraisal. Indeed, the cost-effective 1990 s contributed by optimizing sample throughput and reducing cost of testing thanks to the attractive characteristics of these smallscale toxicity assays. Examples of two such tests developed in the authors' Centre include a Microtox (Vibrio fischeri) microplate bioassay where the light inhibition toxicity endpoint is read with the help of a microluminometer ${ }^{5}$ and a microplate-based trout (Oncorhynchus mykiss) primary hepatocyte bioassay where the cytotoxicity endpoint is read with a microfluorometer. ${ }^{6}$

In going from darkness (1950s) to enlightenment (end of the 1990s), which introduced ecotoxicology into science, two important lessons clearly stand out: first, that contaminant pressures unquestionably trigger the need for effects-based measurements to assess ecotoxicity and second, that ecotoxicology needs toxicity tests representative of different levels of biological organization so as to detect the full toxicity potential of chemicals and complex environmental (liquid and solid) media. Conscious of the historical reasons which led to negative environmental impacts brought on by industrialization and the need for ecotoxicology, laboratories in different parts of the world began to acquire specific types of expertise in this diversified field of the environmental sciences. This was clearly the case in Canada where government cross-country institutions banked on diversified expertise to cope with aquatic ecosystem issues of regional importance (e.g., National Water Research Institute, Burlington, Ontario; Bedford Institute of Oceanography, Dartmouth, Nova Scotia; Freshwater Institute, Fisheries and Oceans Canada, Winnipeg, Manitoba).

What thus follows are descriptions of studies that are largely reflective of work conducted by the authors and their colleagues in the Saint-Lawrence Centre, a research institute of Environment Canada located in Montréal, Canada, with bioassays and biomarkers - the two fundamental pillars of ecotoxicology allowing effects-based measurements of contaminant pressures. Notions of how the use of these two pillars has evolved with time are also intimated as well as issues and needs facing tomorrow's ecotoxicology.

\section{The St-Lawrence River Action Plan: trying to solve a whale of a problem! ...or integrating bioassays as an aid to decision-making}

In the early 1900 s, the population of endemic beluga whales (Delphinapterus leucas) living in the estuary of the Saint-Lawrence River
(SLR) was estimated to be close to 3000 , but by the 1970 s it had dwindled to some 300 individuals. ${ }^{7}$ Biopsies performed on dead whale tissues soon revealed that they were laden with various (in)organic contaminants (e.g., heavy metals, polycyclic aromatic hydrocarbons, polychlorinated biphenyls) indicating that food chain contamination had occurred stemming from upstream industrial point sources of pollution. Because of this bio-magnification of toxicants up to the level of belugas, many animals were found to be dying from immunosuppressive and/or cancer-related diseases. ${ }^{8}$

This highly covered news story led to the creation of the Saint-Lawrence Centre in 1988 and of several five-year Saint-Lawrence River Action Plans thereafter jointly funded by the governments of Canada and that of the province of Quebec to deal with water quality issues. Hence, the first Saint-Lawrence River Action Plan (SLAP) was enacted in 1988 because of deteriorated water quality in the SLR system and the major objective of the first two SLAPs (1988-1998) sought to reduce toxic impact stemming from industrial point source pollution. To identify harmful emissions to the SLR, an integrative ecotoxicological (costeffective) tool capable of assessing the potential toxicity of industrial wastes discharging to the SLR on a common comparative basis was developed known as the potential ecotoxic effects probe (PEEP) index. In brief, the PEEP index is the product of the summation of toxic units generated by several bioassays conducted at different taxonomic levels and effluent flow expressed in $\mathrm{m}^{3} / \mathrm{h}^{9}{ }^{9,10}$ For example, a Pulp and Paper effluent discharging to the SaintLawrence River was determined to have a toxic loading of 647,982 toxic units per $\mathrm{m}^{3} / \mathrm{h}$ emitted to the SLR, as reported in Blaise and Férard 2005. ${ }^{10}$ The PEEP index value for this effluent, after extracting the $\log _{10}$ of its toxic loading, is one of 5.8. Thus, the PEEP index can also be considered to be an environmental Richter scale that evaluates the toxic loading of a series of industrial effluents all discharging to the same aquatic ecosystem. For the first 50 industrial plants investigated, whose effluents were discharging to the SLR and that were selected for priority toxic loading assessment on the basis of their chemical production/ emissions, PEEP index values were shown to vary from 0 (no toxic loading) to 7.8 (very high toxic loading). Application of the PEEP index clearly identified categories of effluents responsible for marked toxic loading to the SLR which then allowed enlightened decisionmaking to proceed with corrective action (clean up) on (classes of) effluents identified as the most potentially harmful to the SLR receiving aquatic ecosystem. Figure 1 illustrates the culprit effluents, in terms of high toxic loading to the SLR, as coming from the Pulp and Paper and Inorganic plant industries. 
PEEP index characterization of the 50 priority industrial effluents discharging to the SLR by 1993 thus contributed to improved environmental protection for the River and to reduction of toxic input to the SLR ecosystem. From 1993-1997, ensuing actions also triggered government/industry negotiated clean-up responses, establishment of site-specific wastewater chemical standards for some effluents and enforcement of new Canadian regulations for the Pulp and Paper sector in 1995. Furthermore, based on a comparison of the 1988 and 1995 chemical loading (i.e., quantity of end-of-pipe contaminants measured by chemical analysis) of the 50 effluents, toxic loading reduction was estimated at $96 \% .^{11}$ Overall, this concerted effort aimed at identifying toxic effluents and at reducing their toxic loading significantly improved SLR water quality. As mentioned at the start of this section, the beluga population in the SLR estuary was at an all- time low of 300 individuals in the 1970 s prior to the SLAP initiative. In 2005, Fisheries and Oceans department biologists (Maurice Lamontagne Institute, Mont-Joli, Quebec, Canada) estimated the whale population to be back to 1000 individuals. ${ }^{12}$ In 2013 , despite evidence of contaminant-related pathologies still prevalent in some animals, ${ }^{8}$ it is now estimated to be close to 1100 (unpublished results of Fisheries and Oceans, Canada, 2013). In conclusion, this is an important success story linked to the first two SLAPs, enabled in part by PEEP index effects-based (bioassay) measurements of industrial effluents, which proved effective in ameliorating SLR water quality.

\section{A few words on sediment assessment}

Lotic and lentic sediments are often the recipients of numerous (in)organic contaminants stemming from aqueous, terrestrial and/or atmospheric sources owing to both natural and anthropogenic causes. Since their contamination can impact benthic biota with resulting negative consequences that can alter structure and function of habitats, appraising sediment ecotoxicity is paramount to ensure the health of aquatic life.

In much the same way as the PEEP index sought to determine the toxic loading of industrial effluents, a similar scale, the sedimenttoxicity (SED-TOX) index, was developed in our Centre to assess sediment quality. This index features applying a battery of bioassays suited to measure the toxicity of different sediment compartments, namely wet sediment, its interstitial water and that of an organic extract of the whole sediment. ${ }^{13}$ The summation of toxic units of the three phases contribute, via a specially-designed formula, a SED-TOX score value $(\mathrm{X})$ varying from $0-2$ that identifies four classes of sediment quality, namely no toxicity $(\mathrm{X}=0)$, weak toxicity $(0<\mathrm{X}<1)$, moderate toxicity $(1 \leq X<2)$ and high toxicity $(X \geq 2)$.

The SED-TOX index was demonstrated to correlate with contaminant concentrations present in sediments of several geographical areas and was also shown to correlate with a specially designed benthic community index, the ICI-SL (Invertebrate community Index for the St. Lawrence River), thereby confirming its scientific validation as an integrating tool enabling reliable assessment and management of contaminated sediments. ${ }^{14}$ The SEDTOX index continues to be useful for studies seeking to undertake inter-site comparisons, for detection/quantification of sediment contamination and extent of impact, for establishing management/remediation priorities, as well as for predicting effects on aquatic communities.

\section{Biomarkers}

While bioassays are essentially conducted in the laboratory to determine classical endpoints based on lethality, growth and reproduction, biomarkers - another key tool of ecotoxicology used to measure ecotoxic effects - comprise relevant biochemical and physiological parameters to assess (geno)toxicological, immunological and reproductive perturbations at the level of individuals. Employed either in laboratory or field studies, biomarkers are commonly reported with fish and invertebrate animal models. Following their first modest appear- ances in the scientific literature as of the 1980 s, biomarker studies have, with time, taken a prominent place in terms of numbers of published articles related to the field of ecotoxicology. Notions of what a biomarker consists of are varied as many definitions have appeared in the literature. ${ }^{15,16}$ In fact, Benford et al. (2000) ${ }^{17}$ have listed over 20 biomarker definitions, the following being one that the authors of this article particularly adhere to: The term biomarker is used in a broad sense to include almost any measurement reflecting an interaction between a biological system and an environmental agent, which may be chemical, physical or biological. Indeed, it is important to appreciate that chemical contaminants are not the only ones capable of modulating biomarker responses, but that physicochemical ${ }^{18,19}$ and biological agents ${ }^{20}$ can as well.

In a manner similar to bioassays, the application of biomarkers has gone from single biomarker use, to multiple-biomarker use, to use in weight-of-evidence approaches. For example, early environmental studies sought to show exposure of fish to heavy metals by measuring metallothionein, ${ }^{21}$ or to show exposure of fish to specific classes of organic contaminants by measuring the CYP4501A enzyme ethoxy-resorufin-ortho-deethylase. ${ }^{22}$ Later on, battery applications of biomarkers simultaneously measured in multiple organs/tissues of animals were conducted to maximize ecotoxicity information, which in turn optimized hazard interpretation potential. For example, an environmental survey conducted to assess the state of health of endemic Mya arenaria soft-shell clams located in different intertidal sites of the Saguenay Fjord (Quebec, Canada) measured a large suite of

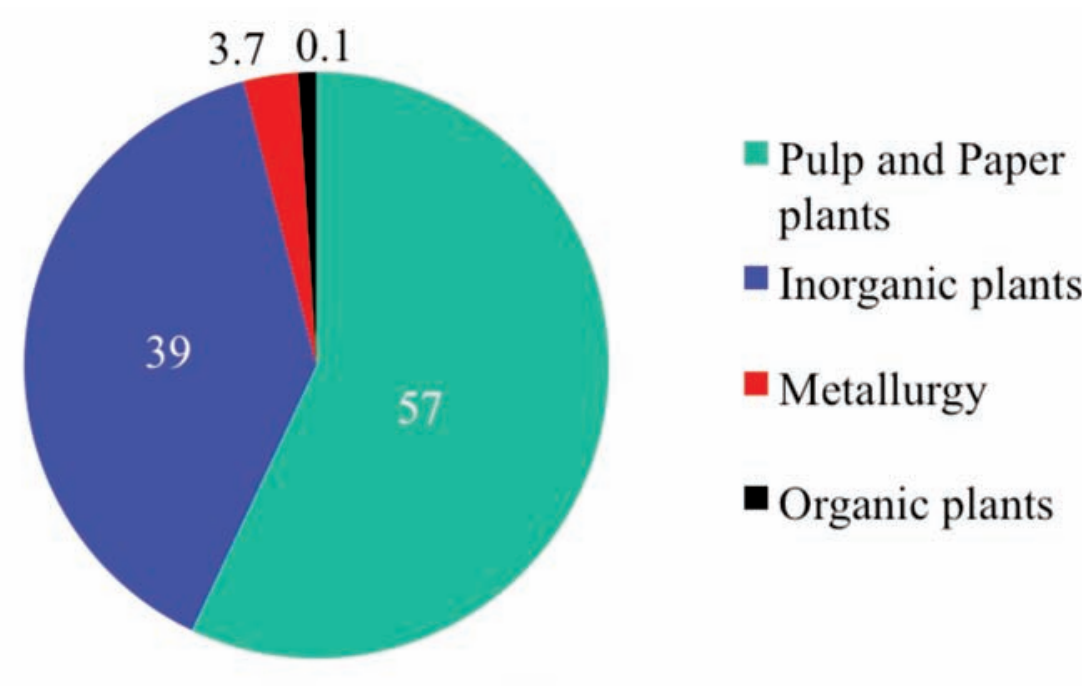

Inorganic plants + P\&P plants produced 96\% of toxic load to the St-Lawrence River!

Figure 1. Relative toxic loading of the priority effluents discharging to the Saint-Lawrence River (see text for details). 
biomarkers including condition factor, energy reserves (glycogen, lipids, proteins), CYP1A1/CYP3A4, metallothioneins, lipid peroxidation, DNA damage, immunotoxicity as well as endocrine disruption biomarkers that contributed valuable knowledge on pollution sources impacting this ecosystem. ${ }^{23,24}$ Nowadays, provided sufficient funding and inter-disciplinary expertise are available, comprehensive investigations, featuring in part biomarkers, known as weight-of-evidence (WOE) approaches are at times undertaken where multiple parameter measurements are generated. For example, WOE studies can include toxicity testing on whole organisms, multiple biomarker measurements, and chemistry on water, sediment and tissue, as well as ecological parameters. ${ }^{25}$

With continuing development in ecotoxicological research that led to increasing numbers of biomarkers, they have often been grouped into different categories based on the type of ecotoxicity information that they engender (Table 1$)^{21,26-39}$. Of notable interest are biomarkers that can intimate exposure to a specific class of chemicals. In this category, for example, we find MT, P4501A and P4503A, responses of which are respectively linked to heavy metal, polycyclic aromatic compounds and drugs and/or naphthenic acids. ${ }^{21,22,26-29}$ Moreover, biomarkers which can relate to population effects on biota are especially important because of the environmental relevance that they can infer toward specific sources of contamination. Examples include biomarkers such as phagocytosis capacity and vitellogenin induction, both of which have been shown respectively tied to immune-suppressive and reproductive perturbations in bivalves. ${ }^{40-42}$ While the biomarkers reported in Table 1 are representative of those presently used in ecotoxicology, this list is far from being exhaus- tive. With the dawning of the age of toxicogenomics, there appears to be a huge potential for developing new biomarkers in future that may help to uncover the modes of action of emerging contaminants such as fire retardants, new pharmaceuticals and nanoparticles.

\section{Biomarker studies in Eastern Canada}

In general, biomarker studies in Canada are conducted for site-specific assessments and/or to undertake large-scale (annual) monitoring programs to investigate long-term trends in water quality. Our research on biomarker measurements in Eastern Canada has largely been conducted with bivalves. The rationale for selecting molluscan shellfish as a bio-indicator species rests on two basic factors. For one, bivalves are sessile and thus reflect environmental water quality conditions that are truly site-specific. For another, as filter feeders they offer good potential to bio-accumulate chemicals from the water column and/or sediments with which they can be in intimate contact. These key features thus enable ecotoxicological investigations to quantify their exposure to contaminants and to measure their effects over space and time. In this section, we briefly discuss selected biomarker results obtained with bivalves impacted by urban effluents, an important point source of mixed (domestic and industrial) pollution impacting receiving waters in Canada ${ }^{43}$ and elsewhere. ${ }^{44}$ The focus is on the immunosuppressive and reproductive consequences of urban effluents on molluscan shellfish, due to the fact that these biomarkers are linked to population effects as indicated previously.

Under a SLAP-funded Urban Effluent
Research Program in place at the St-Lawrence Centre since 1998, Elliptio complanata freshwater mussels were first exposed in the laboratory for $96 \mathrm{~h}$ to varying concentrations of the Montreal wastewater treatment plant (WWTP) effluent. Afterwards, additional mussels were exposed for two months, upstream and downstream of this effluent, in the freshwater portion of the St-Lawrence River employing a standard caging (i.e. field-deployment) methodology. 45

By measuring the responses of a microplatebased phagocytosis assay appraising the capacity of mussel hemocytes to ingest fluorescent bacteria, results showed that phagocytosis activity was significantly suppressed in hemocytes after the 96 h-exposure to high concentrations $(\geq 25 \% \mathrm{v} / \mathrm{v})$ of the WWTP effluent, as well as after the two month caging experiment for mussels exposed downstream of the WWTP emission. ${ }^{34}$ Similarly, phagocytosis measurements generated with endemic Mya arenaria soft-shell clams collected from intertidal zones of the Saguenay Fjord, a major affluent of the SLR estuary (Figure 2), also displayed immunosuppression in animals located in zones impacted by urban effluents. ${ }^{46}$ Immunosuppression in hemocytes has also been observed in other urban effluents to which caged bivalves were exposed. ${ }^{42}$

Under identical exposure and caging conditions as described above, increased vitellogenin (Vg) levels, indicative of estrogen induction, were also observed in both male and female gonads of Elliptio mussels exposed to the Montreal WWTP effluent and following a two-month caging downstream of the effluent plume, suggesting feminization effects brought on by this discharge. ${ }^{35} \mathrm{~A}$ one-year (life cycle) caging experiment of mussels later conducted upstream and at two downstream sites of this same effluent again confirmed higher

Table 1. Types of biomarkers in use for aquatic ecotoxicological studies.

\begin{tabular}{|c|c|c|c|}
\hline Category & Biomarker & Target and/or effect & References \\
\hline $\begin{array}{l}\text { Adaptive, defence or early } \\
\text { biological effects }\end{array}$ & $\begin{array}{l}\text { Metallothionein } \\
\text { Cytochrome P4501A } \\
\text { Cytochrome P4503A }\end{array}$ & $\begin{array}{l}\text { Binds heavy metals } \\
\text { Hydroxylates polycyclic aromatic compounds } \\
\text { Hydroxylates polycyclic aliphatic compounds } \\
\text { (drugs as well as naphthenic acids from oil sands) }\end{array}$ & $\begin{array}{l}\text { Roch and McCarter, } 1984^{21} \\
\text { Isani et al., 200026 } \\
\text { Binelli et al., 200527 } \\
\text { Gagné et al., 2008a } \\
\text { Gagné et al., 2012 }\end{array}$ \\
\hline Damage & $\begin{array}{l}\text { Lipid peroxidation } \\
\text { DNA strand breaks } \\
\text { Micronuclei }\end{array}$ & $\begin{array}{l}\text { Lipids } \\
\text { DNA } \\
\text { Hemocytes and other cells }\end{array}$ & $\begin{array}{l}\text { Quinn et al., } 2012^{30} \\
\text { Black et al., } 1996^{31} \\
\text { Burgeot et al., } 1996^{32}\end{array}$ \\
\hline Immunocompetence & $\begin{array}{l}\text { Lysozyme } \\
\text { Phagocytosis }\end{array}$ & $\begin{array}{l}\text { Degrades bacterial cell walls } \\
\text { Capacity of ingesting foreign microorganisms }\end{array}$ & $\begin{array}{l}\text { Canesi et al., } 2002^{33} \\
\text { Blaise et al., } 2002^{34}\end{array}$ \\
\hline Reproduction & $\begin{array}{l}\text { Vitellogenin } \\
\text { Aspartate transcarbomoylase } \\
\text { AchE (acetylcholine) } \\
\text { Serotonin } \\
\text { Dopamine }\end{array}$ & $\begin{array}{l}\text { Estrogen receptor binding indicative of estrogenicity } \\
\text { Gonadal enzyme involved in DNA synthesis for egg or sperm production } \\
\text { Excitotoxic neurotransmitter; activated by some pesticides and pharmaceuticals } \\
\text { Involved in neurosignalling during feeding and spawning processes } \\
\text { A neurotransmitter involved in feeding and gametogenesis }\end{array}$ & $\begin{array}{l}\text { Gagné et al., } 2001^{35} \\
\text { Mathieu, } 1987^{36} \\
\text { Solé et al., } 2010^{37} \\
\text { Gibbons and Castagna, 1984 } \\
\text { Osada et al., 198739 }\end{array}$ \\
\hline
\end{tabular}


Vg levels downstream as well as demonstrating significant feminization of downstreamexposed (62 and $66 \%$ feminization at two sites) over upstream-exposed (43\% feminization) animals. ${ }^{40}$ In the Saguenay Fjord, gonads of clams collected in areas subjected to urban effluent exposure also displayed significantly higher Vg levels in their gonads over animals located in reference areas. ${ }^{46}$

Overall, results obtained with these two biomarkers (phagocytosis capacity and Vg induction) showed that urban effluents are consistently immunosuppressive and estrogenic with resulting effects at the population level, ${ }^{40,41}$ thereby indicating the need for improved treatment at source of these hazardous discharges. In this respect, investigations on (dis)advantages of applying ozone and ultraviolet treatments to reduce environmental impacts of the Montreal WWTP have recently been reported. ${ }^{18,19}$

\section{Emerging substances: pharmaceuticals}

Urban effluents can be a source of myriads of contaminants among which are pharmaceutical residues of all sorts. Their ecotoxicity has been shown to vary from responses ranging from $<0.1 \mathrm{mg} / \mathrm{L}$ to $>100 \mathrm{mg} / \mathrm{L}$ based on the most sensitive endpoint values (e.g., $\mathrm{LCx}, \mathrm{ECx}$, ICx) generated with suites of bioassays. Overall, micro-algae tend to display more sensitivity toward pharmaceuticals, followed by micro-invertebrates and finally fish. Exceptions for the latter group are hormones, such as ethynil estradiol, that are highly estrogenic toward fish. ${ }^{44,47}$

Indeed, several classes of pharmaceuticals are present (NSAIDs or non-steroidal antiinflammatory drugs, lipid regulators, antibiotics, anticonvulsants, etc.) in urban effluents in Canada, ${ }^{48}$ and particularly in the Montreal WWTP effluent, ${ }^{49}$ thus corroborating the fact that these emissions markedly contribute to the discharge of drugs into aquatic environments. However, concentrations released, essentially ranging from a few $\mathrm{ng} / \mathrm{L}$ to a few dozen $\mu \mathrm{g} / \mathrm{L}$, are insufficient to provoke acute toxicity in aquatic biota. ${ }^{48,49}$ Nonetheless, chronic toxicity owing to long-term exposure of some drugs cannot be excluded. ${ }^{50}$ Neither are hazards stemming from the possible bioaccumulation and biomagnification of drugs with lipophilic properties. The anticonvulsant carbamazepine $(\mathrm{Ko} / \mathrm{w}=2.6)$, for example, present in the Montreal WWTP effluent, bioaccumulated in micro-algae (Pseudokirchneriella subcapitata), and biomagnified to the primary (Thamnocephalus platyurus) and secondary (Hydra attenuata) levels, as shown with an experimental trophic chain developed in our Centre. ${ }^{51}$ Another potential hazard of environmental drug release can be linked to secondary production of oxidative stress resulting from biotransformation. Indeed, we also demonstrated that a $48 \mathrm{~h}$ exposure of Hydra attenuata to caffeine, a stimulant with very low acute toxicity occurring only at concentrations exceeding $100 \mathrm{mg} / \mathrm{L}$, induced xanthine oxidoreductase activity, which may in turn lead to production of oxidative stress, at concentrations close to those present in urban effluents. ${ }^{49}$ There is thus a need for future studies on the ecotoxicity of pharmaceuticals to focus on exploring possible adverse long-term effects to biota resulting from chronic toxicity, from bioaccumulation and biotransformation, as well as from drug biomagnification.

\section{Emerging substances: nanoparticles}

Another class of substances that may likely pose threats toward aquatic organisms in years to come comprises nanoparticles. Environmental research in this area is presently skyrocketing. Because of their small size and shape (1-100 nm), as well as composition, nanoparticles (NP) have novel properties that currently have numerous applications in fields such as biomedicine (medical imaging, drug delivery) and electronics (faster/smaller computers, semi-conductors).

Unprecedented efforts in R\&D to develop novel applications with nanometer-sized mat- ter are growing at a planetary scale and a trillion-dollar market is expected to result from this ongoing industrial boom. While information on release of nanoparticles into the aquatic environment is largely an unknown, ${ }^{52}$ recent studies suggest health and environmental adverse effects linked to some nanoproducts. ${ }^{53-58}$

Since little is yet known about nanotoxicity on living organisms, ecotoxicological research in this area is clearly justified. In our Centre, we examined the ecotoxicity of 11 selected nano-materials (nine metallic and two organic nano-powders) to aquatic biota representative of several taxonomic groups. Toxicity data generated on the 11 NPs reflected a wide spectrum of sensitivity that was biological level-, test- and endpoint-specific, with the most sensitive bioassay responses placing them in hazardous classes lying between 0.1 to $100 \mathrm{mg} / \mathrm{L} .{ }^{59}$ In another study, we conducted testing with the microbial array for risk assessment (MARA) assay, an 11 microbial species 96-well microplate toxicity test measuring growth inhibition, to determine the toxic potential of four metallic nano-powders (MNPs), copper zinc iron oxide, samarium (III) oxide, erbium (III) oxide and holmium (III) oxide). Toxicity testing was also undertaken after the four nano-powdwers were spiked into natural StLawrence River freshwater sediments displaying low, medium and high fines contents. Sediment elutriate toxicity was generally shown to increase as fines contents decreased, suggesting that these metallic nano-powders behave similarly to their nonnanoparticle metal counterparts. Overall, MARA bioassay data indicate that MNP toxici-

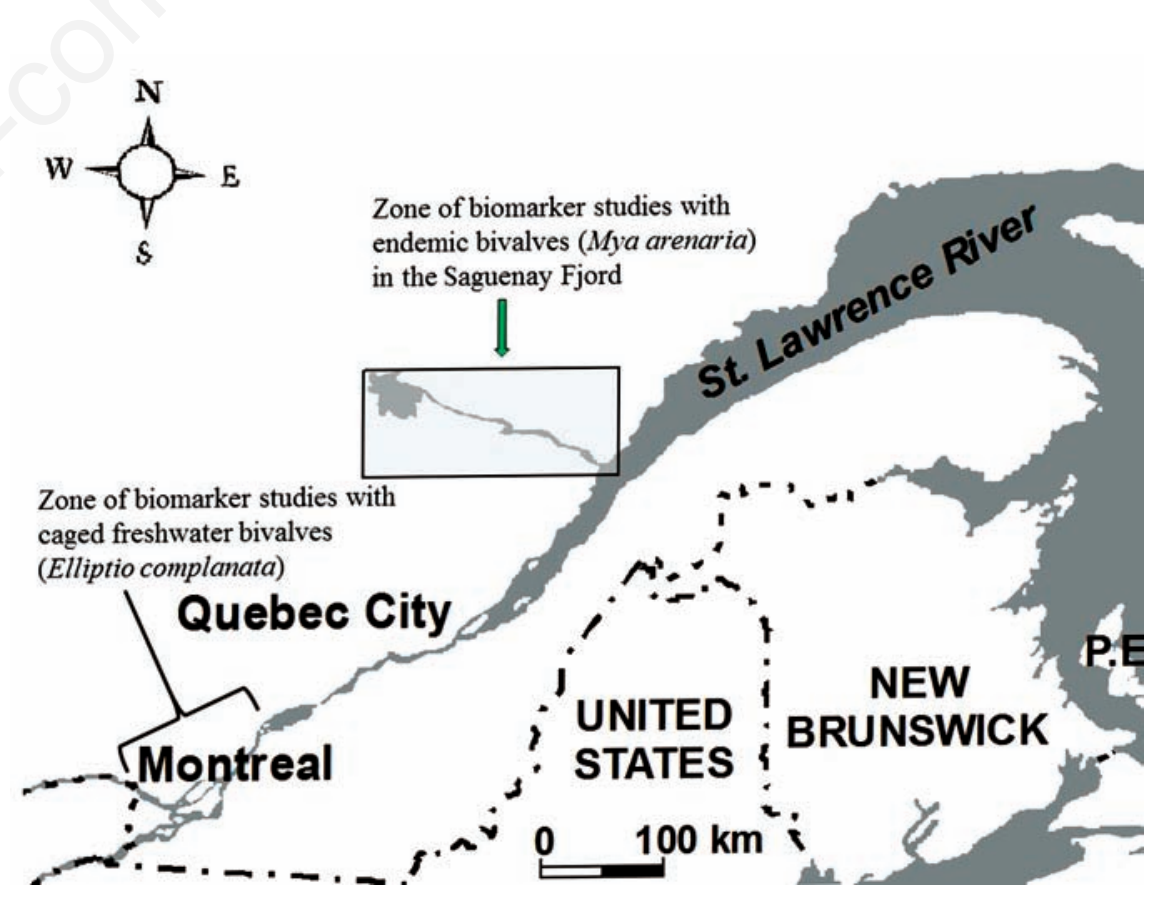

Figure 2. Sites of biomarker studies conducted with caged freshwater mussels (Elliptio complanata) and with native soft-shell clams (Mya arenaria) (see text for details). 
ty can be modulated by sediment grain size and that resulting adverse effects on aquatic biota will in part depend on such sediment characteristics. ${ }^{60}$ These initial investigations suggested that chemicals emerging from nanotechnology may pose a risk to aquatic life in water column and sediment compartments and that further studies on their adverse effects are to be encouraged.

On the biomarker research side for NPs, current research activities focus on the understanding of basic toxic properties of NPs. The toxicity of NPs results from four basic toxic properties ascribed to NPs. ${ }^{61}$ Indeed, nanotoxic effects arise from i) the dissolution of components during degradation (e.g., release of $\mathrm{Ag}+$ from nanosilver), ii) the size and form of nanoparticles including agglomeration/aggregation, iii) surface reactivity and iv) vectorization effects. The release of toxic components from NPs occurs especially in uncoated NPs although this cannot explain all toxic effects. For example, the addition of cysteine, a strong $\mathrm{Ag}^{+}$chelator, only partially blocked micronuclei formation in cells treated with nanosilver. ${ }^{62}$ This indicates that factors other than the release of $\mathrm{Ag}+$ were at play in the formation of micronuclei. The second level of toxicity is related to the size or form of the NPs themselves. Dimensions between 1-100 nm are in the same domain of macromolecules that could lead to potentially harmful steric hindrance interactions. For example, rainbow trout hepatocytes exposed to cadmium-based quantum dots led to increased levels of protein chaperones (proteins involved in the stabilization of protein folding) which were not entirely explained by the release of labile cadmium. ${ }^{63}$ The third level of toxicity involves special properties at the surface of NPs. Properties such as local electrical field, semiconduction, charge density and photochemical properties could lead to important harmful biochemical effects given the very important surface area/volume ratio. For example, the production of an electrical field at the surface of NPs could disrupt local biogenic electrical fields involved in mitochondrial energy production and respiration or depolarization potentials in nerve membranes. Cadmium-based quantum dots were shown to induce oxygen radicals with a characteristic hypsochromic shift in the emission spectra when interacting with thiol-containing peptides at the surface of the quantum dots. ${ }^{64}$ The fourth and last level of toxic risk is associated with the ability of NPs to transport dissolved molecules in biological systems, hence vectorization properties. This represents a major area of research in therapeutics were NPs are produced to vector and target various drugs at specific cellular/tissular sites. For example, glyphosate toxicity was enhanced by the presence of drug-carrying cationic dendrimers to Chlamydomonas reinhardtii algae..$^{65}$

\section{Issues and needs confronting ecotoxicology today}

At the dawn of the $21^{\text {st }}$ century, ecotoxicology continues to be confronted with diverse issues, most of which are essentially linked to lingering problems that are difficult to eliminate or deal with. As intimated previously, continuous technology, creation of new molecules, as well as an ever- increasing human population, all place growing demands on (non)renewable resources of the planet that exacerbate impacts on ecosystems. While certainly non exhaustive, Figure 3 lists some issues of importance that continue to require

Ecotoxicity of mixtures

Immunotoxicity

Continued ecotoxic assessment of emerging chemicals (e.g., under CMPCanada, FIFRA-USA, REACH-Europe)

Anti-fouling agents

Impacts of multiple stressors on aquatic ecosystems

(non)point source pollution

Endocrine disruption

Modes of action of chemical pollutants

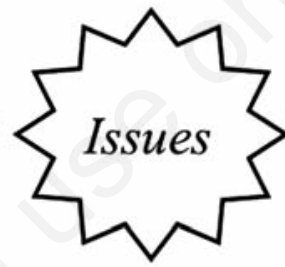

Sediment ecotoxicity Pulse exposure ecotoxicity

Pollution acclimation, adaptation, resistance, tolerance, resilience

(bio)transformation of chemicals

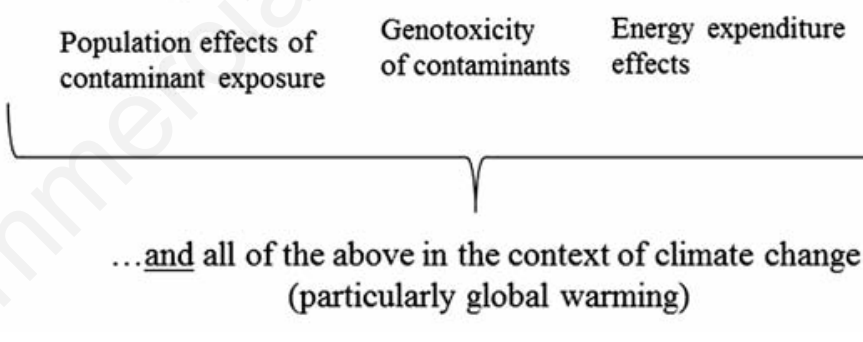

Figure 3. Continuing issues to be addressed by ecotoxicology. CMP, Chemical Management Program (of Canada); FIFRA, Federal Insecticide, Fungicide and Rodenticide Act; REACH, Registration, Evaluation, Authorization and restriction of Chemicals.

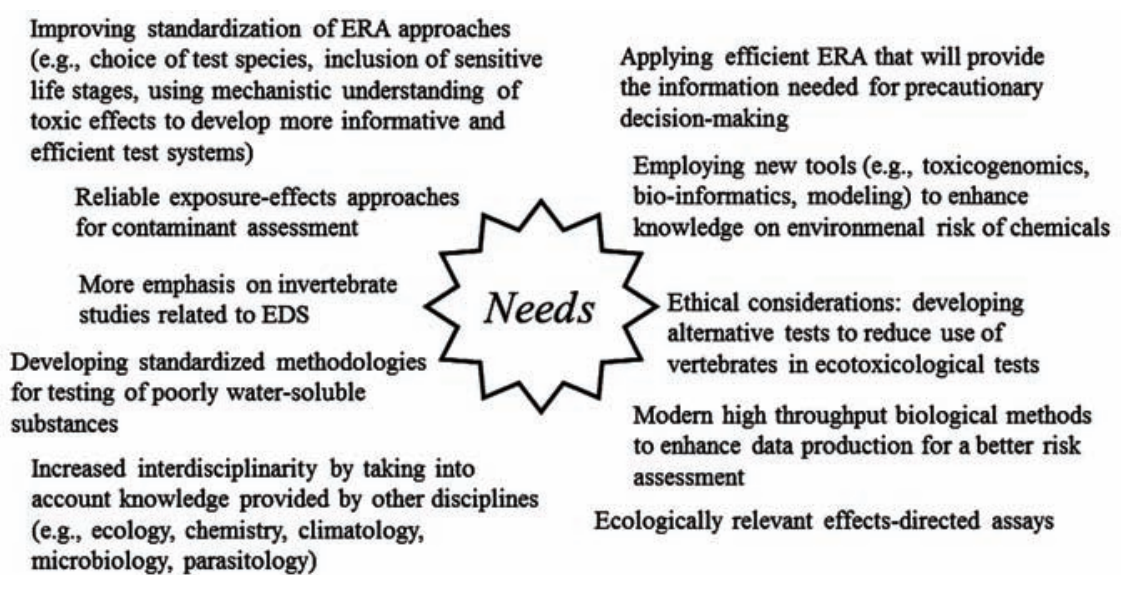

Figure 4. Some important needs to be addressed by ecotoxicology. ERA, environmental risk assessment; EDS, endocrine disruption substances. 
biota or even to increase mortality events in some situations. Such combined effects could thus reduce resistance or tolerance to infection with possible population impacts..$^{20}$ Again, increases in numbers of invasive species linked to global warming are showing that some native predators are shifting their diet toward invasive prey. Such diet shifts may have important parasitological and immunological consequences that could ultimately affect predator fitness via changes in condition and contaminant exposure. Exploring links between invasive prey and parasitism, contaminants and fitness of their native predators thus merit future attention. ${ }^{66}$ Finally, global warming may produce other potential smoking guns via increased release of toxic compounds formed in ice via photo-chemical processes upon melting, thereby adding additional contaminant pressures on wildlife. ${ }^{67}$

Issues requiring attention by ecotoxicology are thus legion and the needs to be addressed are equally enormous. Figure 4 lists some of these (self-explanatory) demands that have been persuasively described in recent publications. ${ }^{68-70}$

\section{General conclusions}

Following environmental pressures stemming from a first industrial revolution in the latter part of the $19^{\text {th }}$ century, and those resulting from continuous technological growth worldwide afterwards, aquatic ecotoxicology has forcibly evolved into a more mature discipline today because of experience gained in coping with numerous contaminant-based issues. Ecotoxicity research studies presented herein offer a glimpse of environmental concerns that were deemed important of appraisal by our EC (Centre Saint-Laurent=SaintLawrence Centre) laboratories in Montreal (Québec, Canada) to protect Saint-Lawrence River water quality. Clearly, other priorities in other parts of Canada or elsewhere will dictate the type of ecotoxicological investigations that should be envisaged to preserve specific aquatic ecosystems thus stimulating different research approaches and strategies. Despite concerted efforts to reduce ecotoxicity globally in past decades, there continues to be increasing environmental issues to deal with now than there were at the time of the first industrial boom in the late $19^{\text {th }}$ century! While it appears difficult to ever win the war waged against ecotoxicity, we can certainly do our best to keep on winning battles. To attain this goal, ecotoxicology will gain markedly through interdisciplinarity by working with, and taking into account knowledge provided by, other disciplines (e.g., ecology, chemistry, climatology, microbiology, parasitology).

\section{References}

1. Blaise C, Sergy G, Wells P, Bermigham N, van Coillie R. Biological testing development, application and trends in Canadian environmental protection laboratories. Toxicity Assess 1988;3:385-406.

2. Blaise C, Costan G. La toxicité létale aiguë des effluents industriels au Québec vis-àvis de la truite arc-en-ciel. Water Poll Res J Canada 1987;22:385 402.

3. Jouany JM. Nuisances et ecologie. Actualités Pharmaceutiques 1971;69:1122.

4. Blaise C, Wells P, Lee K. Microscale testing in aquatic toxicology: introduction, historical perspective, and context. In: Wells $\mathrm{P}$, Lee $\mathrm{K}$, Blaise $\mathrm{C}$, eds. Microscale testing in Aquatic Toxicology Advances, Techniques and Practice. Boca Raton, FL: CRC Lewis Publishers; 1998. pp 1-9.

5. Blaise C, Forghani R, Legault R, Guzzo J, Dubow M. A bacterial toxicity assay performed with microplates, microluminometry and MicrotoxR reagent. Biotechniques 1994;16:932-7.

6. Gagné F, Blaise C. Validation of the rainbow trout hepatocyte model for the ecotoxicity evaluation of industrial wastewaters. Environ Toxicol Water Qual 1997;12:305314.

7. Reeves RR, Mitchell E. Catch history and initial population of white whales, Delphinapterus leucas, in the River and Gulf of St-Lawrence, Eastern Canada. Le Naturaliste Canadien 1984;111:63-121.

8. Martineau D. Beluga whales and ecotoxicity. In: Férard JF, Blaise C, eds. Encyclopedia of aquatic ecotoxicology. Vol. I-II. Dordrecht: Springer; 2013. pp 151-168.

9. Costan G, Bermingham N, Blaise C, Férard JF. Potential ecotoxic effects probe (PEEP): a novel index to assess and compare the toxic potential of industrial effluents. Environ Toxicol Water Qual 1993;8:115-40.

10. Blaise C, Férard JF. Effluent assessment with the PEEP (potential ecotoxic effects probe) index. In: Blaise C, Férard JF, eds. Small-scale freshwater toxicity investigations. Vol. 2. Dordrecht: Springer; 2005. pp 69-87.

11. Thériault F. La réduction des rejets liquides toxiques des 50 établissements industriels prioritaires du Plan d'action Saint-Laurent, Rapport-synthèse 19881995. Environnement Canada, Montréal, région du Québec, Direction de la protection de l'environnement / Ministère de l'Environnement et de la Faune du Québec, Direction régionale de la Montérégie. Saint-Laurent Vision 2000 volet Protection; 1996. 12 pp + tables and appendices.

12. Gosselin JF, Hammill M, Lesage V. Comparison of photographic and visual abundance indices of belugas in the St. Lawrence Estuary in 2003 and 2005. C. S. A. S. C. S. A. Report 2007; Secretariat. Mont-Joli: Maurice Lamontagne Institute; 2007.

13. Bombardier M, Blaise C. Comparative study of the sediment toxicity index, benthic community metrics and contaminant concentrations. Water Qual Res J Canada 2000;4:753-80.

14. Bombardier M. Développement d'outils écotoxicologiques pour l'évaluation de sédiments. Doctoral thesis, Université Paul Verlaine, Metz, France. [In French].

15. Depledge MH, Amaral-Mendes JJ, Daniel B, Halbrook RS, Loepper-Sams P, Moore MN et al. The conceptual basis of the biomarker approach. In: Peakall DB, Shugart LR, eds. Biomarkers: research and application in the assessment of environmental health. Vol. 68. NATO ASI Series H: Cell Biology. Berlin: Springer Verlag; 1993. pp 15-29.

16. Lagadic L, Caquet T, Amiard JC, Ramade F, eds. Biomarqueurs en écotoxicologie. Aspects fondamentaux. Collection Écologie. Paris: Masson; 1997.

17. Benford DJ, Hanley AB, Bottrill K, Oehlschlager S, Balls M, Branca F, et al. Biomarkers as predictive tools in toxicity testing. The Report and Recommendations of ECVAM Workshop 40. ATLA 2000;28:11931.

18. Hébert N, Gagné F, Cejka P, Bouchard B, Hausler R, Cyr DG, et al. Effects of ozone, ultraviolet and peracetic acid disinfection of a primary-treated municipal effluent on the Immune system of rainbow trout (Oncorhynchus mykiss). Comp Biochem Physiol C Toxicol Pharmacol 2008;148:1227.

19. Gagné F, André C, Cejka P, Blaise C, Hausler R. Reduction of alkali-labile phosphates in mussels exposed to primarytreated wastewaters undergoing ozone and ultraviolet disinfection: a pilot study. Water Qual Res J Canada 2009;44:1-5.

20. Marcogliese D, Pietrock M. Combined effects of parasites and contaminants on animal health: parasites do matter. Trends Parasitol 2011;27:123-30.

21. Roch M, McCarter JA. Hepatic metallothionein production and resistance to heavy metals by rainbow trout (Salmo gairdneri) I. Exposed to an artificial mixture of zinc, copper and cadmium. Comp Biochem Physiol C 1984;77:71-5.

22. Hansen PD, Addison RF. The use of mixed function oxidases (MFO) to support biological effects monitoring in the sea. ICES CM/E1990; 33. Copenhagen: International 
Council for the Exploration of the Sea (ICES);1190.

23. Gagné F, Blaise C, Pellerin J, Fournier M, Durand MJ, Talbot A. Relationships between intertidal clam population and health status of the soft-shell clam Mya arenaria in the St. Lawrence Estuary and Saguenay Fjord (Québec, Canada). Environment Intern 2008;34:30-43.

24. Gagné F, Blaise C, Pellerin J, Fournier M, Gagnon C, Sherry J, et al. Impacts of pollution in feral Mya arenaria populations: The effects of clam bed distance from the shore. Sci Total Environ 2009;407:5844-54.

25. Dagnino A, Sforzini S, Dondero F, Fenoglio $\mathrm{S}$, Bona E, Jensen J, et al. 'Weight-of-evidence' approach for the integration of environmental 'triad' data to assess ecological risk and biological vulnerability. Integrat Environ Assess Manag 2008;4: 314-26.

26. Isani G, Andreani G, Kindt M, Carpene E. Metallothioneins (MTs) in marine molluscs. Cell Molec Biol 2000;46:311-30.

27. Binelli A, Ricciardi F, Riva C, Provini A. New evidences for old biomarkers: effects of several xenobiotics on EROD and AChE activities in Zebra mussel (Dreissena polymorpha). Chemosphere 2005;62:5109.

28. Gagné F, Blaise C, André C. Occurrence of pharmaceutical products in a municipal effluent and toxicity to rainbow trout (Oncorhynchus mykiss) hepatocytes. Ecotoxicol Environ Saf 2008;64:329-36.

29. Gagné F, Douville M, André C, Debenest T, Talbot A, Sherry J, et al. Differential changes in gene expression in rainbow trout hepatocytes exposed to extracts of oil sands process-affected water and the Athabasca River. Comp Biochem Physiol C 2012;155:551-9.

30. Quinn B, Schmidt W, O'Rourke K, Hernan R. Effects of the pharmaceuticals gemfibrozil and diclofenac on biomarker expression in the zebra mussel (Dreissena polymorpha) and their comparison with standardised toxicity tests. Chemosphere 2012;84:657-63.

31. Black MC, Ferrell JR, Horning RC, Martin LK. DNA strand breakage in freshwater mussels (Anodonta grandis) exposed to lead in the laboratory and field. Environ Toxicol Chem 1996;15:802-8.

32. Burgeot T, Woll S, Galgani F. Evaluation of the micronucleus test on Mytilus galloprovincialis for monitoring applications along the French coast. Mar Poll Bull 1996;32:39-46.

33. Canesi L, Gallo G, Gavioli M, Pruzzo C. Bacteria-hemocyte interactions and phagocytosis in marine bivalves. Microsc Res Techn 2002;15:469-76.

34. Blaise $\mathrm{C}$, Trottier S, Gagné F, Lallement $\mathrm{C}$,
Hansen P-D. Immunocompetence of bivalve hemocytes by a miniaturized phagocytosis assay. Environ Toxicol 2002; 17:160-9.

35. Gagné F, Blaise C, Salazar S, Hansen PD. Evaluation of estrogenic effects of municipal effluents to the freshwater mussel Elliptio complanata. Comp Biochem Physiol-Part C: Pharmacol Toxicol Endocrinol 2001;128:213-25.

36. Mathieu M. Utilization of aspartate transcarbamylase activity in the study of neuroendocrinal control of gametogenesis in Mytilus edulis. J Explor Biol 1987;241:24752.

37. Solé M, Shaw JP, Frickers PE, Readman JW, Hutchinson TH. Effects on feeding rate and biomarker responses of marine mussels experimentally exposed to propranolol and acetaminophen. Anal Bioanal Chem 2010;396:649-56.

38. Gibbons MC, Castagna M. Serotonin as an inducer of spawning in six bivalve species. Aquaculture 1984;40:189-91.

39. Osada M, Matsutami T, Nomura T. Implication of catecholamines during spawning in marine bivalve molluscs. Intern J Invertebr Repr Dev 1987;12:24152.

40. Blaise C, Gagné F, Salazar M, Salazar S, Trottier S, Hansen P-D. Experimentallyinduced feminisation of freshwater mussels after long-term exposure to a municipal effluent. Fresenius Environ Bull 2003; 12:865-70.

41. Blaise C, Gagné F, Pellerin J. Bivalve population status and biomarker responses in Mya arenaria clams (Saguenay Fjord, Québec, Canada). Fresenius Environ Bull 2003;12:956-60.

42. Gagné F, Blaise C. Immunotoxic effects of selected pharmaceutical products and municipal effluents to Elliptio complanata hemocytes. Comp Biochem Physiol C 2006;143:179-86.

43. Holeton C, Chambers PA, Grace L. Wastewater release and its impacts on Canadian waters. Can J Fish Aquat Sci 2011;68:1836-59.

44. Kestemont P, Depiereux S. Sewage treatment plant effluents and aquatic ecotoxicology. In: Férard JF, Blaise C, eds. Encyclopedia of aquatic ecotoxicology. Vol. I-II. Dordrecht: Springer; 2013. pp 10471062.

45. Salazar MH, Salazar SM. Standard guide for conducting in situ field bioassays with marine, estuarine and freshwater bivalves, E2122-01. In: Annual book of ASTM standards. West Conshohocken: American Society for Testing and Materials (ASTM); 2001; P30.

46. Gagné F, Blaise C, Pellerin J, Fournier M. Etudes de biomarqueurs chez la mye com- mune (Mya arenaria) du fjord du Saguenay: bilan de recherches (1997 à 2006)/Biomarker studies of the soft-shell clam (Mya arenaria) in the Saguenay Fjord: research results (1997-2006). Rev Sci Eau 2009;22:253-9.

47. Webb SF. A data-based perspective on the environmental risk assessment of Human pharmaceuticals I - collation of available ecotoxicity data. In: Kümmerer $\mathrm{K}$, ed. Pharmaceuticals in the environment, sources, fate, effects and risks. 2nd ed. Berlin: Springer; 2004. pp 317-361.

48. Metcalfe CD, Koenig BG, Bennie DT, Servos M, Ternes TA, Hirsch R. Occurrence of neutral and acidic drugs in the effluents of Canadian sewage treatment plants. Environ Toxicol Chem 2003;22:2872-80.

49. Blaise C, Gagné F, Eullaffroy P, Férard JF. Ecotoxicity of selected pharmaceuticals of urban origin discharged to the SaintLawrence River (Québec, Canada): a review. Braz J Aquat Sci Technol 2006; 10: 29-51.

50. Garric J. Emerging issues in ecotoxicology: pharmaceuticals and personal care products (PPCPs). In: Férard JF, Blaise C, eds. Encyclopedia of aquatic ecotoxicology. Vol. I-II. Dordrecht: Springer; 2013. pp 407427.

51. Vernouillet G, Eullaffroy P, Lajeunesse A, Blaise $C$, Gagné $F$, Juneau P. Toxic effects and bioaccumulation of carbamazepine evaluated by biomarkers measured in organisms of different trophic levels. Chemosphere 2010;80:1062-8.

52. Moore MN. Do nanoparticles present ecotoxicological risks for the health of the aquatic environment? Environ Intern 2006;32:967-76.

53. Lovern SB, Klaper R. Daphnia magna mortality when exposed to titanium dioxide and fullerene (C60) nanoparticles. Environ Toxicol Chem 2006;25:1132-7.

54. Oberdörster E, Zhu S, Blickley McClellanGreen P, Haasch ML. Ecotoxicology of carbon-based engineered nanoparticles: effects of fullerene (C-60) on aquatic organisms. Carbon 2006;44:1112-20.

55. Sharma C, Sarkar S, Periyakaruppan A, Barr J, Wise K, Thomas R, et al. Singlewalled carbon nanotubes induce oxidative stress in rat lung epithelial cells. J Nanosci Nanotech 2007;7:2466-72.

56. Chen Z, Meng H, Xing G, Chen C, Zhao Y, Jia $G$ et al. Acute toxicological effects of copper nanoparticles in vivo. Toxicol Lett 2006;163:109-120.

57. Chen Z, Meng H, Xing G, Chen C, Zhao Y. Toxicological and biological effects of nanoparticles. Int J Nanotech 2007;4:17996.

58. Zurita JL, Jos A, del Peso A, Salguero M, Camean AM, Lopez-Artiguez M, et al. 
Toxicological assessment of indium nitrate on aquatic organisms and investigation of effects in the PLHC-1 fish cell line. Sci Total Environ 2007;387:155-65.

59. Blaise C, Gagné F, Férard JF, Eullaffroy P. Ecotoxicity of selected nano-materials to aquatic organisms. Environ Toxicol 2008; 23:591-8.

60. Santos MA, Monteiro RTR, Blaise C, Gagné F, Bull K, Férard JF. Influence of sediment grain size on elutriate toxicity of inorganic nano-materials. Water Qual Res J Canada 2009;44:201-10.

61. Gagné F, Gagnon C, Blaise C. Aquatic nanotoxicology: a review. Res Trends 2008;4:114.

62. Kawata K, Osawa M, Okabe S. In vitro toxicity of silver nanoparticles at noncytotoxic doses to HepG2 human hepatoma cells.
Environ Sci Technol 2009;43:6046-51.

63. Gagné F, Maysinger D, André C, Blaise C. Cytotoxicity of aged cadmium-telluride quantum dots to rainbow trout hepatocytes. Nanotoxicol 2008;2:113-20.

64. Aryal BP, Neupane KP. Metallothioneins initiate semiconducting nanoparticle cellular toxicity. Small 2006;2:1159-63.

65. Petit A-N, Debenest T, Gagné F. Dendrimers increase glyphosate formulation toxicity to Chlamydomonas reinhardtii. Fresenius Environ Bull 2012;21:16.

66. Bulté G, Robinson SA, Forbes MR, Marcogliese DM. Is there such thing as a parasite free lunch? the direct and indirect consequences of eating invasive prey. EcoHealth 2012;9:6-16.

67. Blaha L. Photo-toxicity in ice. In: Férard JF,
Blaise C, eds. Encyclopedia of aquatic ecotoxicology. Vol. I-II. Dordrecht: Springer; 2013. pp 845-850.

68. Breitholtz M, Ruden C, Hansson SO, Bengtsson BE. Ten challenges for improved ecotoxicological testing in environmental risk assessment. Ecotoxicol Environ Safety 2006;63:324-35.

69. Artigas J, Arts G, Babut M, Barra Caracciolo A, Charles S, Chaumot A, et al. Towards a renewed research agenda in ecotoxicology. Environ Poll 2012;160:201-6.

70. Vindimian E. Environmental research needs (in ecotoxicology) in relation to public policies. In: Férard JF, Blaise C, eds. Encyclopedia of aquatic ecotoxicology. Vol. I-II. Dordrecht: Springer; 2013. pp 437-442. 